\title{
Migration of Non-Native Predator Asp (Leuciscus aspius) from a Reservoir Poses a Potential Threat to Native Species in Tributaries
}

\author{
Nikola Pfauserová ${ }^{1, *(1)}$, Ondřej Slavík ${ }^{1}$, , Pavel Horký ${ }^{1}$, Jitka Kolářová ${ }^{2}$ and Tomáš Randák ${ }^{2}$ \\ 1 Department of Zoology and Fisheries, Faculty of Agrobiology, Food and Natural Resources, Czech \\ University of Life Sciences Prague, Kamýcká 129, Prague 6, 16521 Suchdol, Czech Republic; \\ oslavik@af.czu.cz (O.S.); pavel.horky.r@gmail.com (P.H.) \\ 2 Research Institute of Fish Culture and Hydrobiology, South Bohemian Research Center of Aquaculture and \\ Biodiversity of Hydrocenoses, Faculty of Fisheries and Protection of Waters, University of South Bohemia in \\ České Budějovice, Zátiší 728/II, 38925 Vodňany, Czech Republic; kolarova@frov.jcu.cz (J.K.); \\ trandak@frov.jcu.cz (T.R.) \\ * Correspondence: pfauserova@af.czu.cz
}

Received: 26 May 2019; Accepted: 19 June 2019; Published: 25 June 2019

\begin{abstract}
The introduction of non-native species and human-altered habitats are currently the main threats to freshwater ecosystems. Due to predation and competition, biological invaders can cause extinctions and imperil the status of native species, and this phenomenon is enhanced by habitat alteration, for example, dam construction. In addition to river fragmentation caused by dam construction, the impact of non-native species migrating from reservoirs on native assemblages in their tributaries should be considered from a long-term perspective. The present study focused on asp (Leuciscus aspius), an artificially introduced piscivorous cyprinid that became established in the Lipno Reservoir (Czech Republic). Asp regularly occur in a tributary, the Vltava River, where twenty-five individuals were captured, radio-tagged, and tracked for five consecutive years. Asp occurrence in the tributary was highest during spring due to the upstream migration of spawning fish, and this was interconnected with a movement activity peak in March when the temperature reached $6{ }^{\circ} \mathrm{C}$. The fish migrated a maximum distance of $31 \mathrm{~km}$, and the probability of asp occurrence in the tributary was sex-dependent, with more females than males. Some individuals occupied the Vltava River not only for spawning but remained until the temperatures dropped below $10^{\circ} \mathrm{C}$. This study shows how non-native predators use reservoirs for wintering but feed and spawn in tributaries.
\end{abstract}

Keywords: fish; non-native species; biological invasion; radio telemetry; migration; sex-dependent; homing

\section{Introduction}

The introduction of non-native species (NNS) often ensues as a result of anthropogenic disturbance and is one of the main threats to the biodiversity of freshwater ecosystems [1-3]. Biological invaders can cause extinctions and imperil native species due to predation, competition for resources, hybridization, disease transmission, and habitat degradation and alteration [4-6]. Overall, the rate of introductions and the patterns and threats associated with biotic invaders reflect the patterns of human activities, all of which have increased substantially in recent decades. Human population growth and movement, global trade, and environmental alteration have together created great opportunities for unintentional introductions $[7,8]$. Moreover, anthropogenic non-native fish introductions are often driven by economic benefits and often occur alongside the globalization of fish culture based on introduced species [5,9]. 
Trans- and intracontinental fish introductions have a long history and are driven by several motivations, including aquaculture enhancement, improvement of wild stocks, ornamental purposes, biomanipulation, and sport fishing [2]. Simply stated, an NNS is a species that is introduced intentionally or accidentally or acts as an independent invader that must disperse across barriers naturally or via indirect human action. The term "invasive species" was coined later and can be defined as an NNS with significant risk attached to its introduction [5,10].

The escape of aquaculture species and their establishment in wild local ecosystems may become a significant issue, especially in freshwater ecosystems with relatively high endemism [11-13]. Fish NNS have been introduced as aquaculture species in more than 85 countries worldwide and are known to have adverse ecological impacts [11]. However, aquaculture alone is not responsible for the spread of NNS globally; for example, Gambusia sp., which was introduced in more than 40 countries for the biocontrol of mosquito larvae, altered native fish assemblages [14,15], and this fish has had a negative impact on a wide range of invertebrates, amphibians, and other fish species [16]. In addition, wels catfish (Silurus glanis) (Linnaeus, 1758) was introduced throughout Europe as a valued game fish via intentional releases for angling purposes, aquaculture, and fisheries resources [17] and seemed to exert low pressure on well-established assemblages [18]. Regardless, there is a potential impact on native species that might be enhanced by anthropogenic disturbances and natural conditions. For particular environments (e.g., lakes), biological invaders have been recognized as one of the greatest threats to native species $[17,19]$. A wide adaptability range and a predisposition for successful invasion may be well illustrated, for example, by catfish using man-made fish passages as feeding sites during the spawning migrations of salmonids [20].

In addition, altered seasonal regimes (e.g., temperature and precipitation) caused by global climate change drive migrations of organisms to extended distribution as well as shifts in home ranges [18,21-23]. Moreover, species abundance is affected by many factors that are often associated with the loss of spawning grounds, lateral obstacles, and changes in temperature and flow regimes [24-26]. Human-made reservoirs are locations where these factors collectively affect fish assemblage (i.e., cause a reduction in species abundance [25,27] and an increase in the proportion of alien species [28]). In addition, man-made dams alter assemblage compositions, even in tributaries. For example, species that are originally riverine (e.g., asp (Leuciscus aspius) (Linnaeus, 1758) [29] and roach (Rutilus rutilus) (Linnaeus, 1758) [30]) influence the assemblages above reservoirs through their upstream migrations [31,32]. These migrations are well documented among cyprinid species, which generally migrate upstream and return after spawning [33-35]. This pattern has been observed in both rivers [34,36,37] and reservoirs [31,38]. The spawning migration occurs in spring, and movements in summer and autumn are driven by dispersal and/or refuge seeking [26].

In this study, we observed periodic fish migration between a reservoir and a tributary. These migrations were driven by reproduction and could be partly understood as trophic migration. Asp, a large, piscivorous, benthopelagic, rheophilic, and potamodromous predator [36,39], displays both stationary and migratory behavior during its lifetime. During spawning migrations, asp are able to move up to $60 \mathrm{~km}$ per day [36], and these fish are also known to migrate from reservoirs to tributaries for reproduction in spring. Their presence as a predator in tributaries may consequently affect the trophic equilibrium of native assemblages [31,38]. Asp exhibit high individual variability in diel movement within the area of their home ranges, and their activity differs seasonally [36,40]. Nonetheless, there is a lack of detailed evidence regarding how far asp migrate, how long individuals remain in rivers, and how or if the behaviors of males and females differ. Addressing these questions is important for precisely predicting their impact on native assemblages.

In this study, 25 asp individuals were captured, radio-tagged, and studied over a 5-year period. Their movement patterns within the Lipno Reservoir and its tributary, the Vltava River, were monitored by radio telemetry tracking. Here, we provide evidence that asp, an NNS artificially introduced into the Lipno Reservoir, have become successfully established and reproduce periodically in the main tributary. The findings of this study contribute to the literature regarding the consequences of riverine 
system fragmentation (i.e., reservoir construction) on fish migratory behavior and raises questions regarding the spread of fish to non-native ranges.

\section{Materials and Methods}

\subsection{Study Area}

This study was performed in the headwaters of the Vltava River, which flows into the Lipno Reservoir, Šumava National Park, the Czech Republic (Figure 1). The primary study area included approx. $30 \mathrm{~km}$ of the main free-flowing channel of the Vltava River and the first $15 \mathrm{~km}$ of the Lipno Reservoir. The study area was delimited upstream by the occurrence of asp in the Vltava River and downstream by the excessive depth of the reservoir. Regular attempts to track the fish outside the primary study area were conducted; however, the success was very low due to the limited range of the radio telemetry transmitters at depths greater than $5 \mathrm{~m}$. The Vltava River headwaters consist of mountainous (approx. 730-756 m above sea level) and oligotrophic streams with a predominantly pristine morphology. The main channel gradient within the study area is low, where the river meets the reservoir the gradient is only $0.4 \%$. The Lipno Reservoir represents a typical heavily modified waterbody (surface area $46.5 \mathrm{~km}^{2}$; length $42 \mathrm{~km}$, maximum depth $25 \mathrm{~m}$; maximum width $5 \mathrm{~km}$ ) with multifunctional uses, including hydropower, flood protection, flow augmentation, and recreational activities, such as angling and sailing.

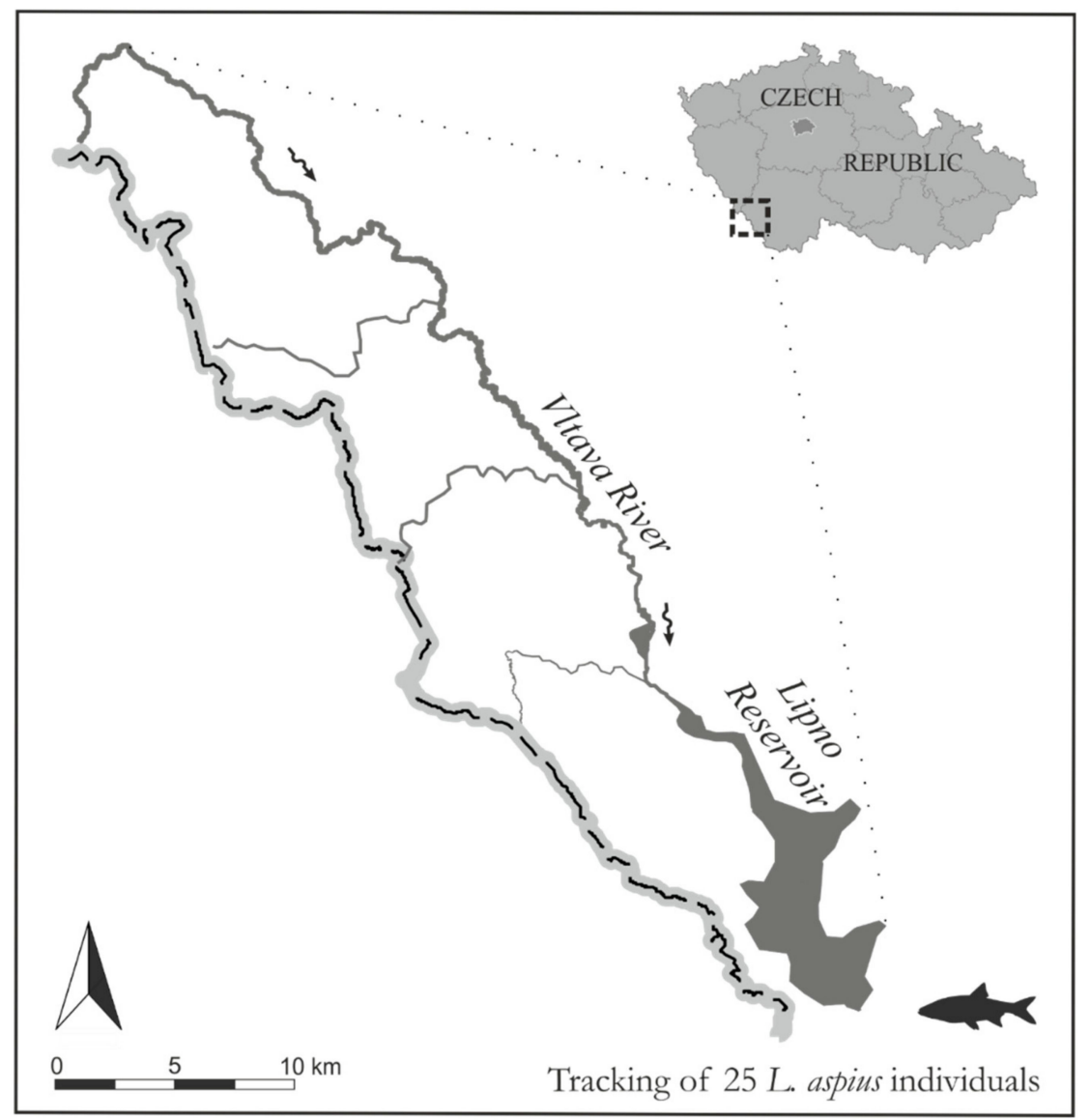

Figure 1. A map of the study area-the Lipno Reservoir and its tributary the Vltava River (Czech Republic).

\subsection{Fish Origin and Tagging}

In total, the 25 L. aspius individuals that were caught by electrofishing ( $650 \mathrm{~V}, 4 \mathrm{~A}$, pulsed D.C.) in the Vltava River during two consecutive spring spawning seasons (2014-2015) were implanted with 
radio telemetry tags. The fish were anaesthetized with 2 -phenoxy-ethanol $\left(0.2 \mathrm{~mL} . \mathrm{L}^{-1}\right)$, measured (standard length, LS; mean $517 \mathrm{~mm}$, range 385-680 mm), and weighed (body size; mean $2217 \mathrm{~g}$, range 1100-5620 g). Radio transmitters were implanted into the fish body cavities through a midventral incision that was closed with three separate stitches using sterile braided absorbable sutures (Coated Vicryl ${ }^{\circledR}$, Ethicon Inc., Somerville, NJ, USA). The sex of each individual was determined during a surgical procedure. The mass of the transmitter never exceeded $2 \%$ of the body mass of the fish [41]. Two types of transmitters (Lotek Engineering, Inc., Newmarket, ON, Canada) were used in our study. Eleven L. aspius were tagged with MCFT2-3FM transmitters equipped with temperature sensors (operational life 1432 days), and fourteen L. aspius were tagged with MCFT-3L transmitters (operational life 1686 days). Prior to release in a location close to the site of capture, the fish were held in cages for approx. 30 min until they had recovered their body balance and showed spontaneous swimming activity.

\subsection{Monitoring Procedures}

The fish were monitored over five consecutive years from May 2014 until December 2018. The primary study area was tracked by boat once every 14 days on average. During the spring spawning migrations from February to April [36], the fish's longitudinal movements were fast (i.e., over $1 \mathrm{~km}$ per day upstream), and they were tracked more frequently (i.e., weekly at a minimum); during winter, the entire length of the study site was tracked at least once per month (fish were tracked by walking in the harsh conditions of ice and snow cover, which prevented fast and efficient tracking). The tracking equipment included a radio receiver (Lotek SRX_600; Lotek Engineering Inc., Newmarket, ON, Canada) and a three-element Yagi antenna. The fish's positions in the river network were recorded and stored in a GPS (GPS map 76S, Garmin LTD., Olathe, KS, USA). The temperature data from the sensor transmitters were stored automatically and subsequently downloaded from the receiver.

All of the experimental procedures complied with valid legislative regulations (Law no. 246/1992, $\S 19$, art. 1, letter c).

\subsection{Habitat Measurements}

The water flow (mean $4.5 \mathrm{~m}^{3} \mathrm{~s}^{-1}$; range $1.163-46.8 \mathrm{~m}^{3} \mathrm{~s}^{-1}$ ) was automatically recorded daily at a gauging station located within the study stretch above the reservoir. The water temperature $\left({ }^{\circ} \mathrm{C}\right)$ was obtained from the sensor transmitters and was used to show the threshold when the asp entered and left the Vltava River.

\subsection{Data Analyses}

The position of each fish was assigned a binary variable value for 'occurrence in the Vltava River', where a value of ' 1 ' indicated occurrence in the Vltava River, and a value of ' 0 ' indicated occurrence in the Lipno Reservoir. The distance $(\mathrm{m})$ between the locations of a fish for two successive tracking occasions was used as a proxy of 'movement activity'. The fish position and movement data were analyzed using Map Source version 5.3 (GPS map 76S, Garmin LTD., Olathe, KS, USA). The 'number of detections' was expressed as the number of successful tracking occasions and was counted for every individual fish. The temperature sensor transmitters (range from -6 to $34{ }^{\circ} \mathrm{C} ; 50$ stepwise temperature values; i.e., accuracy to $0.8^{\circ} \mathrm{C}$ ) allowed individual L. aspius temperature data to be saved automatically every $5 \mathrm{~s}$. Every fish was assigned one mean temperature value for every tracking occasion.

\subsection{Statistical Analysis}

Statistical analyses were performed using the SAS software package (SAS Institute Inc., Cary, NC, USA, version 9.4, wWw.sas.com). When needed, the data were $\log _{10}$ transformed to meet normality requirements. The asp movement activity and number of detections were analyzed using mixed models with random factors (PROC MIXED with a normal distribution for movement activity; PROC GLIMMIX with a Poisson distribution for the number of positions). Mixed models are a generalization of the standard models used (e.g., in the GLM procedure), with the generalization being that the data 
are permitted to exhibit correlation and nonconstant variability. This is an approach to cope with repeated measures experiments using human or animals as subjects, whereby subjects are declared random because they are selected from the larger population for which generalizations are sought [42]. Therefore, individual fish were used as random factors in the present study. More detailed information about the mixed model can be found elsewhere [43,44].

The significance of each explanatory variable (i.e., month and sex) was assessed using the $F$ test, and least-squares means (LSM; henceforth referred to as 'adjusted means') were subsequently computed. Differences between the class variables were tested with the $t$ test. We used Tukey-Kramer adjustment for multiple comparisons, and degrees of freedom were calculated using the Kenward-Roger method [45].

The data regarding the binary variable 'occurrence in the Vltava River' were subjected to the $\chi^{2}$ test using the generalized estimating equation (GEE) approach [46] with the GENMOD procedure with binomial distributions. The GEE approach is an extension of generalized linear models and provides a semi-parametric approach to longitudinal data analysis. In this study, the GENMOD procedure was designed to estimate the probability of occurrence in the Vltava River (i.e., probability equal to 1) versus occurrence in the Lipno Reservoir (i.e., probability equal to 0 ) in relation to the season and sex of the tagged fish.

\section{Results}

Nine of the twenty-five tagged fish were never successfully detected after release. These fish presumably migrated downstream to the reservoir after tagging, as was shown for the other tagged fish, and their fate is unknown. The remaining sixteen fish that were used for the further analyses were detected during, on average, 13 tracking occasions (range 1-46 detections per individual; Table 1), and their mean movement activity was $2653 \mathrm{~m}$ (range 3-31,169 m) between two successive tracking intervals.

Table 1. Tagged asp individuals and their basic characteristics, including the number of detections and number of returns to the Vltava River for spawning.

\begin{tabular}{|c|c|c|c|c|c|}
\hline Fish ID & Sex & $\begin{array}{c}\text { Standard } \\
\text { Length }(\mathrm{mm})\end{array}$ & Body Size (g) & $\begin{array}{l}\text { Number of } \\
\text { Detections }\end{array}$ & $\begin{array}{c}\text { Number of } \\
\text { Returns }\end{array}$ \\
\hline 3 & male & 480 & 1635 & 4 & 2 \\
\hline 6 & female & 680 & 5620 & 8 & 0 \\
\hline 7 & male & 560 & 2570 & 0 & 0 \\
\hline 8 & male & 650 & 3990 & 4 & 1 \\
\hline 11 & male & 510 & 1975 & 4 & 2 \\
\hline 12 & male & 610 & 3340 & 8 & 0 \\
\hline 13 & male & 660 & 4630 & 0 & 0 \\
\hline 16 & male & 540 & 2240 & 0 & 0 \\
\hline 23 & female & 460 & 1745 & 0 & 0 \\
\hline 24 & male & 575 & 2675 & 6 & 2 \\
\hline 32 & female & 455 & 1255 & 13 & 2 \\
\hline 36 & male & 480 & 1930 & 0 & 0 \\
\hline 37 & male & 450 & 1100 & 24 & 2 \\
\hline 39 & male & 450 & 1350 & 18 & 4 \\
\hline 57 & female & 580 & 2800 & 46 & 4 \\
\hline 59 & female & 470 & 1565 & 26 & 3 \\
\hline 60 & male & 385 & 1205 & 18 & 4 \\
\hline 63 & female & 465 & 1360 & 24 & 2 \\
\hline 140 & male & 530 & 2255 & 1 & 0 \\
\hline 141 & male & 465 & 1540 & 0 & 0 \\
\hline 142 & male & 530 & 2160 & 0 & 0 \\
\hline 146 & male & 470 & 1535 & 0 & 0 \\
\hline 150 & male & 465 & 1470 & 1 & 0 \\
\hline 151 & male & 480 & 1540 & 1 & 0 \\
\hline 152 & male & 520 & 1935 & 0 & 0 \\
\hline
\end{tabular}


The occurrence of asp in the Vltava River was primarily related to spawning. This finding was supported by the fact that the probability of occurrence in the Vltava River was highest during spring $\left(x^{2}=83.93\right.$, d.f. $=3, p<0.0001$; Figure 2$)$ and that the peak of movement activity occurred in March $\left(F_{6,81.6}=3.62, p<0.0031\right.$; Figure 3$)$. In general, asp entered the Vltava River during the second half of March when the temperatures exceeded $6{ }^{\circ} \mathrm{C}$ and remained there for several weeks for spawning. During this time, large shoals of asp containing hundreds of individuals were visually observed and concentrated at the spawning sites within $4 \mathrm{~km}$ of the Vltava River. Homing of tagged individuals to these spawning sites during consecutive years was detected to within $1 \mathrm{~m}$ of the position in the previous year (mean $919 \mathrm{~m}$, range 1-2600 m).

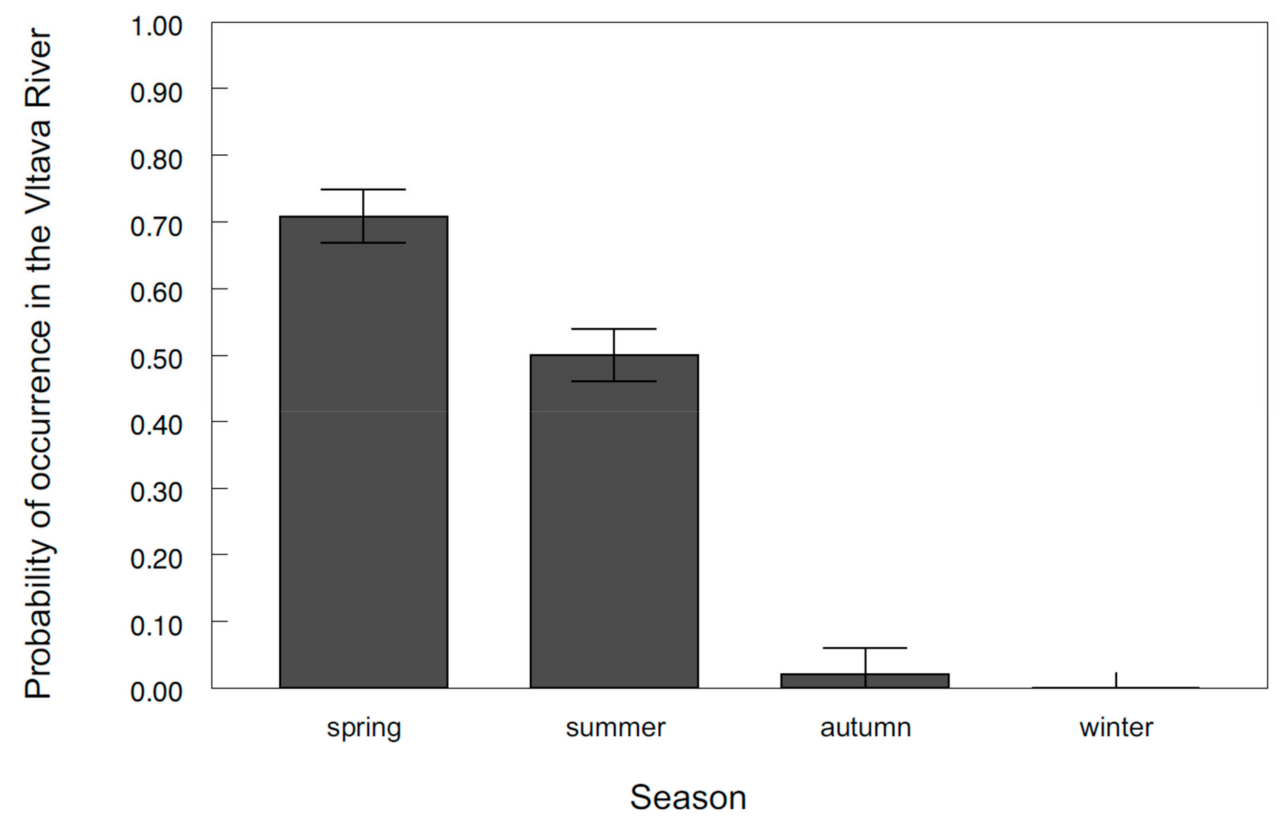

Figure 2. Probability of asp occurrence in the Vltava River across seasons. The values are the means \pm the standard error (S.E.).

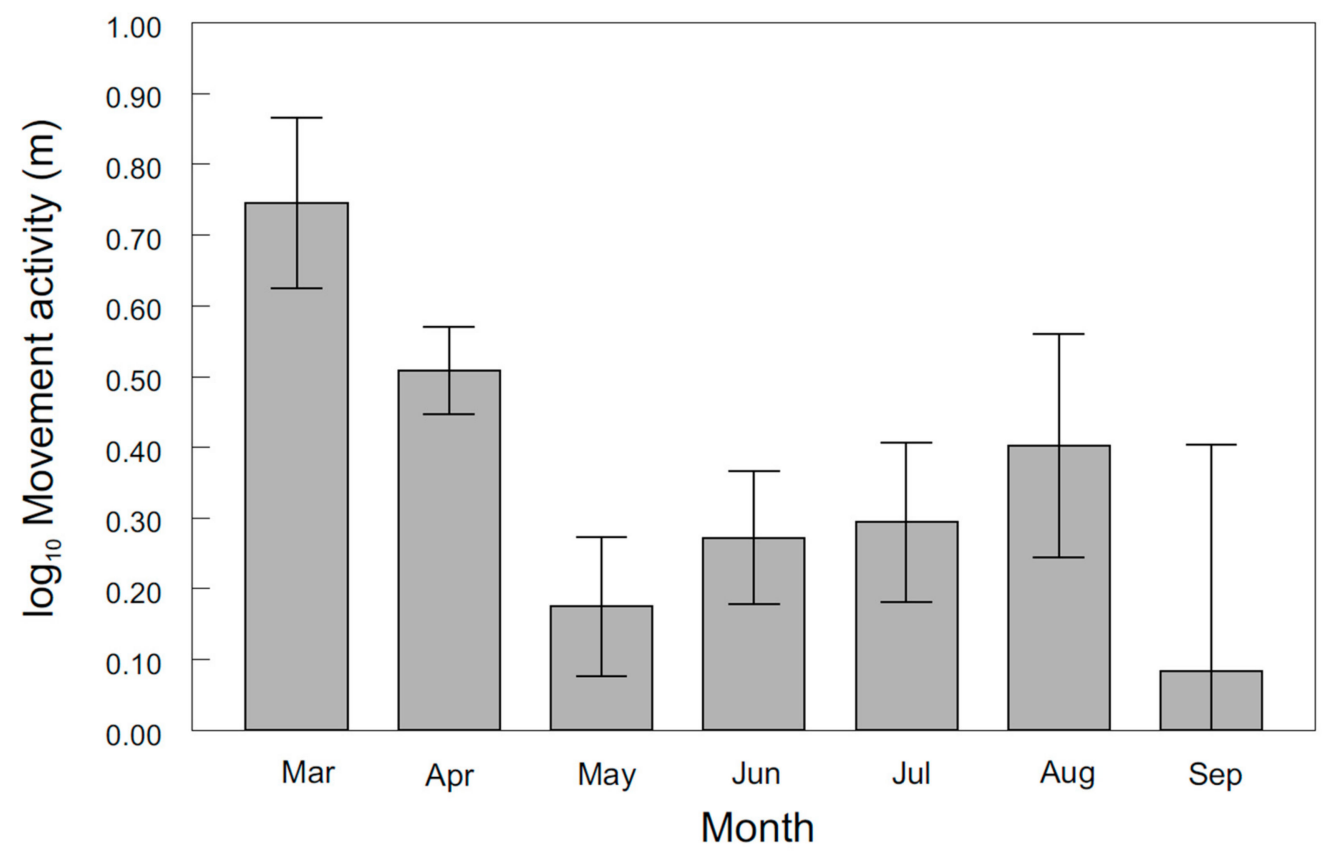

Figure 3. Asp movement activity in the Vltava River across months. The values are the means \pm the standard error (S.E.). 
The return of tagged individuals from the Lipno Reservoir to the Vltava River was detected, on average, during two spring spawning seasons (range from 0 to 4 returns). The probability that fish would return to the Vltava River was higher for females than for males $\left(\chi^{2}=6.49\right.$, d.f. $=1$, $p<0.0109$; Figure 4A). Females were also detected more often than were males $\left(F_{1,16.24}=5.81, p<0.0281\right.$; Figure $4 \mathrm{~B}$ ), suggesting that the females generally stayed in the shallower sections of the reservoir that were closer to the tributary where they could be easily detected. The individuals that remained in the Vltava River during summer and early autumn stayed in the downstream sections near the intake into the reservoir. All tagged fish returned to the reservoir for wintering when the temperatures in the river dropped below $10^{\circ} \mathrm{C}$.

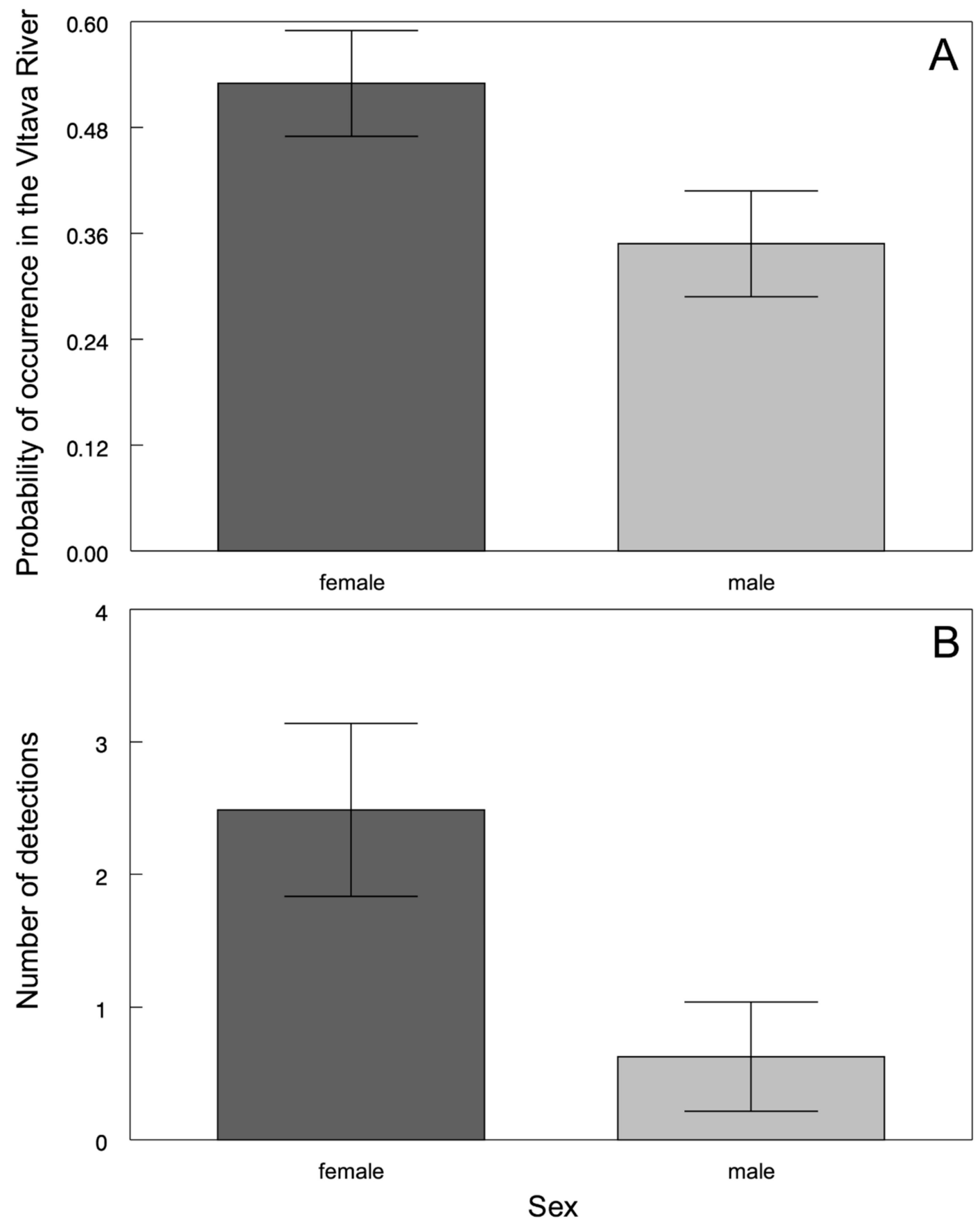

Figure 4. Sexually determined differences in the probability of asp occurrence in the Vltava River (A) and the number of detections (B). The values are the means \pm the standard error (S.E.). 


\section{Discussion}

This study shows that asp are regularly found in the Vltava River, a tributary of the Lipno Reservoir, during their upstream migrations, as driven by spawning and foraging habitat requirements. We tracked asp individuals for four consecutive spawning seasons and detected their seasonal movements. Asp, which are obligatory tributary spawners, reproduce once per year [31], and their migratory behavior peaks twice (i.e., in spring due to spawning and in autumn due to wintering migrations) [40]. In early spring, asp begin the overall spawning migration period as they migrate upstream and are followed by other cyprinid species. After spawning, asp return quickly to the reservoir, and not even juveniles remain in the river for a long time [31]. However, according to our results, some individuals do not return immediately and may compete for resources with native species in the tributary. Because the presence of predators in a river affects communities in both positive and negative ways [4], we suggest a possible effect of asp presence. The negative impact of non-native predators on fish assemblage compositions can be illustrated by decreases in species abundance [47] (e.g., the decline in haplochromines in African lakes caused predominantly by Nile perch (Lates niloticus) (Linnaeus, 1758) introduction) [48]). Asp is known to coexist with species such as pikeperch (Sander lucioperca) (Linnaeus, 1758), with reduced negative competitive interactions and utilization of different prey resources [49]. Regardless, there are no studies of the impact of asp as a trophic competitor or predator on native species when assigning food resources in an invaded river (e.g., on native salmonids).

Our data demonstrate significant differences in movement activity during the year. The Lipno Reservoir asp regularly migrate upstream to the Vltava River. Our results suggest that the peak of activity is connected to the spawning migration and that movement activity is stable during the rest of the year. After the peak in April, the activity of the fish decreased as a consequence of the stable size of the home range; after expending large amounts of energy for spawning, asp spent the oncoming months recovering, foraging, and finally migrating for wintering. Fredrich [36] distinguished two summer and winter habitats that were occupied by asp in the Elbe River; in our study, the Lipno Reservoir serves as a counterpart to the winter habitat. The activity of fish in the Elbe River is similar to the results of our study, as asp occupied their home range to forage and grow for most of the year and returned periodically to their spawning sites. Asp occurrence in the tributary appeared to be temperature limited. Although some individuals stayed in the river for a prolonged period of time, all fish returned to the reservoir for wintering (i.e., asp entered the river when the temperature exceeded $6{ }^{\circ} \mathrm{C}$ and returned to the reservoir when the temperature finally dropped below $\left.10{ }^{\circ} \mathrm{C}\right)$. These results (i.e., temperature-limited migrations) are consistent with those of previous studies $[31,36,40,50]$; moreover, Brodersen et al. [50] suggested that temperature, partial migrations, and trophic dynamics are closely interconnected. The partial migration of asp (i.e., not all individuals returned to the reservoir after spawning [31]) might be a stimulus for the subsequent chain reaction. Most of the partial migrations of cyprinids that have been studied have focused on wintering migrations [50,51], revealing that this migration is driven by a trade-off between predation risk and growth potential (i.e., foraging efficiency) [52-55]. Apparently, migrations are tightly linked to trophic dynamics, beginning at lower trophic levels (i.e., phyto- and zooplankton and consumer abundance [50]), and culminating at the other end of the food chain (i.e., fish predators). The asp partial migration (i.e., occurrence in the river after spawning for a prolonged period of time) may encroach on native assemblages in tributaries. These migrations might directly affect prey species (e.g., roach (Rutilus rutilus) [56]), compete with other species (e.g., non-native salmonids largely replaced indigenous galaxiid fishes in New Zealand [57]), or could alter subsidies and affect distant food webs as a cascading reaction (e.g., the introduction of rainbow trout (Oncorhynchus mykiss) (Walbaum, 1792) gradually depressed riparian spider abundance in Japan [58]).

Reproductive homing is a well-studied phenomenon that is known to confer advantages with regard to reproductive success [59] and is well documented in salmonid [60] and cyprinid [30,37,61,62] species. Our results suggest that asp exhibited strong fidelity to spawning sites concentrated within $4 \mathrm{~km}$ of the Vltava River, and differences with respect to sex were observed. The probability of 
occurrence of females was higher in the tributary, and females were detected more often than were males. These results may be interpreted as a difference in preferred habitats based on sex. Detection is dependent on the section of the reservoir that an individual inhabits; in the upper, shallower part of the reservoir, fish are likely to be detected, whereas in deeper parts, they are not. Another sex-dependent phenomenon was previously observed in asp, as the amount of time spent at spawning sites differed between the sexes (i.e., males arrived at the spawning grounds earlier and departed later than did females) [31,38]. According to our results, female asp returned to the spawning grounds more often and were observed to retrace their migration more regularly than were males. Even in disturbed environments (e.g., near dams or weirs), the traditional upstream spawning migration behavior may continue; namely, fish populations may possibly utilize historical spawning sites (i.e., reproductive homing) or establish new spots to reproduce [63,64]. However, not all species are able to adapt, and for some, dam construction may be lethal (e.g., the extinction of Coreius heterodon (Bleeker, 1864) and Rhinogobius typus (Bleeker, 1871) in the upper parts of the dammed Hanjiang River in China [63]).

In conclusion, this study shows that anthropomorphically altered habitats, particularly dams, impose threats onto native communities, as illustrated by the spread of non-native species. The introduced fish predator, asp, utilized the reservoir as a wintering refuge and the tributary for a significant part of the year as a spawning habitat and foraging site, where allocated food resources may affect native species due to trophic competition or predation.

\section{Conclusions}

One of the threats to freshwater biodiversity is the introduction of non-native species in anthropologically altered habitats [2]. Such examples are dams that interrupt stream continuity, affect the structure of fish assemblages [27], and introduce species with a natural occurrence that does not match the location of the dam. The evidence from this study suggests that the species established in the dam undertake upstream migration to tributaries for spawning and consequently create a competitive environment for indigenous species in terms of predation or trophic competition. This phenomenon was illustrated by the predatory fish asp, which exploit tributary resources from spring to summer and utilize the dam as a wintering habitat. Because asp exhibit apparent site fidelity and regular migration between dams and tributaries, it is appropriate to consider the influence of these migrating fish as a significant manifestation of biological invasion.

Author Contributions: Conceptualization: O.S.; methodology: O.S. and P.H.; validation: N.P., O.S., and P.H.; formal analysis: P.H.; investigation: O.S. and J.K.; data curation: N.P.; writing-original draft preparation: N.P.; writing-review and editing: O.S., J.K., and T.R.

Funding: This work was supported by the European Regional Development Fund Project "Centre for the investigation of synthesis and transformation of nutritional substances in the food chain in interaction with potentially harmful substances of anthropogenic origin: comprehensive assessment of soil contamination risks for the quality of agricultural products" (No. CZ.02.1.01/0.0/0.0/16_019/0000845).

Acknowledgments: We thank Jan Turek, Vladimír Žlábek, Jan Lepič, and Roman Grabic for support with the field work.

Conflicts of Interest: The authors declare no conflict of interest. The funders had no role in the design of the study, in the collection, analyses, or interpretation of data, in the writing of the manuscript, or in the decision to publish the results.

\section{References}

1. Sala, O.E.; Chapin, F.S.; Armesto, J.J.; Berlow, E.; Bloomfield, J.; Dirzo, R.; Huber-Sanwald, E.; Huenneke, L.F.; Jackson, R.B.; Kinzig, A.; et al. Global biodiversity scenarios for the year 2100. Science 2000, 287, 1770-1774. [CrossRef]

2. Dudgeon, D.; Arthington, A.H.; Gessner, M.O.; Kawabata, Z.I.; Knowler, D.J.; Lévêque, C.; Naiman, R.J.; Prieur-Richard, A.H.; Soto, D.; Stiassny, M.L.J.; et al. Freshwater biodiversity: Importance, threats, status and conservation challenges. Biol. Rev. Camb. Philos. Soc. 2006, 81, 163-182. [CrossRef] [PubMed] 
3. Kiruba-Sankar, R.; Velmurugan, A.; Saravanan, K.; Dam Roy, S.; Praveen Raj, J.; Raymond Jani Angel, J.; Lohith Kumar, K. Invasive Species in Freshwater Ecosystems-Threats to Ecosystem Services. In Biodiversity and Climate Change Adaptation in Tropical Islands; Sivaperuman, C., Velmurugan, A., Singh, A., Jaisankar, I., Eds.; Elsevier Inc.: Amsterdam, The Netherlands, 2018; pp. 257-296. ISBN 9780128130643.

4. Mack, R.N.; Simberloff, D.; Lonsdale, W.M.; Evans, H.; Clout, M.; Bazzaz, F.A. Biotic invasions: Causes, epidemiology, global consequences, and control. Ecol. Appl. 2000, 10, 689-710. [CrossRef]

5. Gozlan, R.E.; Britton, J.R.; Cowx, I.; Copp, G.H. Current knowledge on non-native freshwater fish introductions. J. Fish Biol. 2010, 76, 751-786. [CrossRef]

6. Roy, H.E.; Bacher, S.; Essl, F.; Adriaens, T.; Aldridge, D.C.; Bishop, J.D.D.; Blackburn, T.M.; Branquart, E.; Brodie, J.; Carboneras, C.; et al. Developing a list of invasive alien species likely to threaten biodiversity and ecosystems in the European Union. Glob. Chang. Biol. 2019, 25, 1032-1048. [CrossRef] [PubMed]

7. Lodge, D.M. Biological invasions: Lessons for ecology. Trends Ecol. Evol. 1993, 8, 133-137. [CrossRef]

8. Vitousek, P.M.; Mooney, H.A.; Lubchenco, J.; Melillo, J.M. Human Domination of Earth's Ecosystems. In Urban Ecology: An International Perspective on the Interaction Between Humans and Nature; Springer: New York, NY, USA, 2008; pp. 3-13. ISBN 9780387734118.

9. Asche, F.; Roll, K.H.; Sandvold, H.N.; Sørvig, A.; Zhang, D. Salmon aquaculture: Larger companies and increased production. Aquac. Econ. Manag. 2013, 17, 322-339. [CrossRef]

10. Copp, G.H.; Bianco, P.G.; Bogutskaya, N.G.; Eros, T.; Falka, I.; Ferreira, M.T.; Fox, M.G.; Freyhof, J.; Gozlan, R.E.; Grabowska, J.; et al. To be, or not to be, a non-native freshwater fish? J. Appl. Ichthyol. 2005, 21, 242-262. [CrossRef]

11. Casal, C.M.V. Global documentation of fish introductions: The growing crisis and recommendations for action. Biol. Invasions 2006, 8, 3-11. [CrossRef]

12. Carosi, A.; Ghetti, L.; La Porta, G.; Lorenzoni, M. Ecological effects of the European barbel Barbus barbus (L., 1758) (Cyprinidae) invasion on native barbel populations in the Tiber River basin (Italy). Eur. Zool. J. 2017, 84, 420-435. [CrossRef]

13. Cook, E.J.; Ashton, G.; Campbell, M.; Coutts, A.; Gollasch, S.; Hewitt, C.; Liu, H.; Minchin, D.; Ruiz, G.; Shucksmith, R. Non-Native Aquaculture Species Releases: Implications for Aquatic Ecosystems. In Aquaculture in the Ecosystem; Springer: Dordrecht, The Netherlands, 2008; pp. 155-184. ISBN 9781402068102.

14. Welcomme, R.L. A history of international introduction of inland aquatic species. ICES Mar. Sci. Symp. 1992, 194, 3-14.

15. Azevedo-Santos, V.M.; Vitule, J.R.S.; Pelicice, F.M.; García-Berthou, E.; Simberloff, D. Nonnative fish to control aedes mosquitoes: A controversial, harmful tool. Bioscience 2017, 67, 84-90. [CrossRef]

16. Pyke, G.H. Plague Minnow or Mosquito fish? A review of the biology and impacts of introduced Gambusia species. Annu. Rev. Ecol. Evol. Syst. 2008, 39, 171-191. [CrossRef]

17. Cucherousset, J.; Horky, P.; Slavík, O.; Ovidio, M.; Arlinghaus, R.; Boulêtreau, S.; Britton, R.; García-Berthou, E.; Santoul, F. Ecology, behaviour and management of the European catfish. Rev. Fish Biol. Fish. 2018, 28, 177-190. [CrossRef]

18. Copp, G.G.H.; Robert Britton, J.; Cucherousset, J.; García-Berthou, E.; Kirk, R.; Peeler, E.; Stakènas, S.; Britton, J.R.; Cucherousset, J. Voracious invader or benign feline? A review of the environmental biology of European catfish Silurus glanis in its native and introduced ranges. Fish Fish. 2009, 10, 252-282. [CrossRef]

19. Gherardi, F. Biological Invasions in Inland Waters: An Overview. In Biological Invaders in Inland Waters: Profiles, Distribution, and Threats; Gherardi, F., Ed.; Springer: Dordrecht, The Netherlands, 2007; pp. 3-25. ISBN 978-1-4020-6029-8.

20. Boulêtreau, S.; Gaillagot, A.; Carry, L.; Tétard, S.; De Oliveira, E.; Santoul, F. Adult Atlantic salmon have a new freshwater predator. PLoS ONE 2018, 13, e0196046. [CrossRef]

21. Perry, A.L.; Low, P.J.; Ellis, J.R.; Reynolds, J.D. Ecology: Climate change and distribution shifts in marine fishes. Science 2005, 308, 1912-1915. [CrossRef] [PubMed]

22. Britton, J.R.; Cucherousset, J.; Davies, G.D.; Godard, M.J.; Copp, G.H. Non-native fishes and climate change: Predicting species responses to warming temperatures in a temperate region. Freshw. Biol. 2010, 55, 1130-1141. [CrossRef] 
23. Pederson, J.; Mieszkowska, N.; Carlton, J.T.; Gollasch, S.; Jelmert, A.; Minchin, D.; Occhipinti-Ambrogi, A.; Wallentinus, I. Climate Change and Non-Native Species in the North Atlantic. In ICES Status Report on Climate Change in the North Atlantic; ICES Cooperative Research Report No. 310; ICES: Copenhagen, Denmark, 2011; pp. 174-190.

24. Kaukorantana, M.T.; Pennanen, J. Propagation and management of the asp, Aspius aspius (L.), in Finland. In Proceedings of the Management of Freshwater Fisheries: A symposium organized by the European Inland Fisheries Advisory Commission, Goteborg, Sweden, 31 May-3 June 1988; Vandensen, W., Steinmetz, B., Hughes, R., Eds.; Pudoc: Wageningen, The Netherlands, 1990; pp. 67-73.

25. Radinger, J.; Essl, F.; Hölker, F.; Horký, P.; Slavík, O.; Wolter, C. The future distribution of river fish: The complex interplay of climate and land use changes, species dispersal and movement barriers. Glob. Chang. Biol. 2017, 23, 4970-4986. [CrossRef]

26. Benitez, J.P.; Dierckx, A.; Nzau Matondo, B.; Rollin, X.; Ovidio, M. Movement behaviours of potamodromous fish within a large anthropised river after the reestablishment of the longitudinal connectivity. Fish. Res. 2018, 207, 140-149. [CrossRef]

27. Musil, J.; Horký, P.; Slavík, O.; Zbořil, A.; Horká, P. The response of the young of the year fish to river obstacles: Functional and numerical linkages between dams, weirs, fish habitat guilds and biotic integrity across large spatial scale. Ecol. Indic. 2012, 23, 634-640. [CrossRef]

28. Liew, J.H.; Tan, H.H.; Yeo, D.C.J. Dammed rivers: Impoundments facilitate fish invasions. Freshw. Biol. 2016, 61, 1421-1429. [CrossRef]

29. Vostradovský, J. On the biology of asp (Aspius aspius L.) in the water-supply reservoir Švihov (Želivka). Anim. Husb. 1974, 19, 683-688.

30. L'Abée-Lund, J.H.; Vøllestad, L.A. Feeding migration of roach, Rutilus rutilus (L.), in Lake Arungen, Norway. J. Fish Biol. 1987, 30, 349-355. [CrossRef]

31. Hladík, M.; Kubečka, J. Fish migration between a temperate reservoir and its main tributary. Hydrobiologia 2003, 504, 251-266. [CrossRef]

32. Hladík, M.; Kubečka, J.; Mrkvička, T.; Čech, M.; Draštík, V.; Frouzová, J.; Hohausová, E.; Matěna, J.; Matěnová, V.; Kratochvíl, M.; et al. Effects of the construction of a reservoir on the fish assemblage in an inflow river. Czech J. Anim. Sci. 2008, 53, 537-547. [CrossRef]

33. Lucas, M.C.; Baras, E. Methods for studying spatial behaviour of freshwater fishes in the natural environment. Fish Fish. 2003, 1, 283-316. [CrossRef]

34. Benitez, J.P.; Nzau Matondo, B.; Dierckx, A.; Ovidio, M. An overview of potamodromous fish upstream movements in medium-sized rivers, by means of fish passes monitoring. Aquat. Ecol. 2015, 49, 481-497. [CrossRef]

35. Benitez, J.P.; Ovidio, M. The influence of environmental factors on the upstream movements of rheophilic cyprinids according to their position in a river basin. Ecol. Freshw. Fish 2018, 27, 660-671. [CrossRef]

36. Fredrich, F. Long-term investigations of migratory behaviour of asp (Aspius aspius L.) in the middle part of the Elbe River, Germany. J. Appl. Ichthyol. 2003, 19, 294-302. [CrossRef]

37. Kulíšková, P.; Horký, P.; Slavík, O.; Jones, J.I. Factors influencing movement behaviour and home range size in ide Leuciscus idus. J. Fish Biol. 2009, 74, 1269-1279. [CrossRef] [PubMed]

38. Šmejkal, M.; Baran, R.; Blabolil, P.; Vejřík, L.; Prchalová, M.; Vebrová, L.; Ricard, D.; Kubečka, J.; Sajdlová, Z.; Mrkvička, T.; et al. Seasonal and daily protandry in a cyprinid fish. Sci. Rep. 2017, 7, 1-9. [CrossRef] [PubMed]

39. Kottelat, M.; Freyhof, J.J. Handbook of European Freshwater Fishes; IUCN Publication: Gland, Switzerland, 2007; ISBN 978-2-8399-0298-4.

40. Horký, P.; Slavík, O. Diel and seasonal rhythms of asp Leuciscus aspius (L.) in a riverine environment. Ethol. Ecol. Evol. 2017, 29, 449-459. [CrossRef]

41. Winter, J.D. Underwater Biotelemetry. In Fisheries Techniques; Nielson, Larry A., Johnson, D.L., Eds.; American Fisheries Society: Bethesda, MD, USA, 1983; pp. 371-395.

42. SAS Institute Inc. SAS/STAT ${ }^{\circledR} 9.1$ User's Guide; SAS Institute Inc.: Cary, NC, USA, 2004; ISBN 1-59047-243-8.

43. Breslow, N.E.; Clayton, D.G. Approximate Inference in Generalized Linear Mixed Models. J. Am. Stat. Assoc. 1993, 88, 9 .

44. Littell, R.C.; Milliken, G.A.; Stroup, W.W.; Wolfinger, R.D.; Schabenberger, O. SAS ${ }^{\circledR}$ for Mixed Models, Second Edition; SAS Institute Inc.: Cary, NC, USA, 2006; ISBN 1-59047-500-3. 
45. Kenward, M.G.; Roger, J.H. Small sample inference for fixed effects from restricted maximum likelihood. Biometrics 1997, 53, 983-997. [CrossRef] [PubMed]

46. Liang, K.Y.; Zeger, S.L. Longitudinal data analysis using generalized linear models. Biometrika 1986, 73, 13-22. [CrossRef]

47. Cucherousset, J.; Olden, J.D. Ecological impacts of non-native freshwater fishes. Fisheries 2011, 36, $215-230$. [CrossRef]

48. Goudswaard, K.; Witte, F.; Katunzi, E.F.B. The invasion of an introduced predator, Nile perch (Lates niloticus, L.) in Lake Victoria (East Africa): Chronology and causes. Environ. Biol. Fishes 2008, 81, 127-139. [CrossRef]

49. Vašek, M.; Matěna, J.; Říha, M.; Jůza, T.; Peterka, J.; Vejříková, I.; Blabolil, P.; Eloranta, A.P.; Kubečka, J.; Šmejkal, M. Stable isotopes and gut contents indicate differential resource use by coexisting asp (Leuciscus aspius) and pikeperch (Sander lucioperca). Ecol. Freshw. Fish 2018, 27, 1054-1065. [CrossRef]

50. Brodersen, J.; Nicolle, A.; Nilsson, P.A.; Skov, C.; Brönmark, C.; Hansson, L.A. Interplay between temperature, fish partial migration and trophic dynamics. Oikos 2011, 120, 1838-1846. [CrossRef]

51. Chapman, B.B.; Skov, C.; Hulthén, K.; Brodersen, J.; Nilsson, P.A.; Hansson, L.-A.; Brönmark, C. Partial migration in fishes: definitions, methodologies and taxonomic distribution. J. Fish Biol. 2012, 81, 479-499. [CrossRef] [PubMed]

52. Brönmark, C.; Skov, C.; Brodersen, J.; Nilsson, P.A.; Hansson, L.A. Seasonal migration determined by a trade-off between predator avoidance and growth. PLoS ONE 2008, 3, e1957. [CrossRef] [PubMed]

53. Skov, C.; Baktoft, H.; Brodersen, J.; Brönmark, C.; Chapman, B.B.; Hansson, L.A.; Anders Nilsson, P. Sizing up your enemy: Individual predation vulnerability predicts migratory probability. Proc. R. Soc. B Biol. Sci. 2011, 278, 1414-1418. [CrossRef] [PubMed]

54. Chapman, B.B.; Hulthén, K.; Blomqvist, D.R.; Hansson, L.A.; Nilsson, J.Å.; Brodersen, J.; Anders Nilsson, P.; Skov, C.; Brönmark, C. To boldly go: Individual differences in boldness influence migratory tendency. Ecol. Lett. 2011, 14, 871-876. [CrossRef] [PubMed]

55. Brönmark, C.; Nilsson, P.A.; Skov, C.; Hulthén, K.; Chapman, B.B.; Brodersen, J.; Hansson, L.-A. There and back again: migration in freshwater fishes. Can. J. Zool. 2013, 92, 467-479. [CrossRef]

56. Krpo-Ćetković, J.; Hegediš, A.; Lenhardt, M. Diet and growth of asp, Aspius aspius (Linnaeus, 1758), in the Danube River near the confluence with the Sava River (Serbia). J. Appl. Ichthyol. 2010, 26, 513-521. [CrossRef]

57. Flecker, A.S.; Townsend, C.R. Community-wide consequences of trout introduction in New Zealand streams. Ecol. Appl. 1994, 4, 798-807. [CrossRef]

58. Baxter, C.V.; Fausch, K.D.; Murakami, M.; Chapman, P.L. Fish invasion restructures stream and forest Food webs by interrupting reciprocal prey subsidies. Ecology 2004, 85, 2656-2663. [CrossRef]

59. Mobley, K.B.; Granroth-Wilding, H.; Ellmen, M.; Vähä, J.-P.; Aykanat, T.; Johnston, S.E.; Orell, P.; Erkinaro, J.; Primmer, C.R. Home ground advantage: Local Atlantic salmon have higher reproductive fitness than dispersers in the wild. Sci. Adv. 2019, 5, eaav1112. [CrossRef]

60. Lucas, M.C.; Baras, E. Migration of Freshwater Fishes; Blackwell Science: Hoboken, NJ, USA, 2001; ISBN 0632057548 .

61. Smith, R.J.F. Social Behaviour, Homing and Migration. In Cyprinid Fishes: Systematics, Biology and Exploitation; Winfield, I.J., Nelson, J.S., Eds.; Springer: Dordrecht, The Netherlands, 1991; pp. 509-529. ISBN 978-94-011-3092-9.

62. L'Abáe-Lund, J.H.; Vøllestad, L.A. Homing precision of roach Rutilus rutilus in Lake Arungen, Norway. Environ. Biol. Fishes 1985, 13, 235-239. [CrossRef]

63. Liu, J.K.; Yu, Z.T. Water quality changes and effects on fish populations in the Hanjiang River, China, following hydroelectric dam construction. Regul. Rivers Res. Manag. 1992, 7, 359-368. [CrossRef]

64. Irving, D.B.; Modde, T. Home-range fidelity and use of historic habitat by adult Colorado pikeminnow (Ptychocheilus lucius) in the White River, Colorado and Utah. West. North Am. Nat. 2000, 60, 16-25.

(C) 2019 by the authors. Licensee MDPI, Basel, Switzerland. This article is an open access article distributed under the terms and conditions of the Creative Commons Attribution (CC BY) license (http://creativecommons.org/licenses/by/4.0/). 